\title{
How Locally Designed Access and Use Controls Can Prevent the Tragedy of the Commons in a Mexican Small-Scale Fishing Community
}

\author{
XAVIER BASURTO \\ School of Public Administration and Policy, University of Arizona, \\ Arizona, USA, and Comunidad y Biodiversidad AC, Sonora, Mexico
}

\begin{abstract}
The Seri people, a self-governed community of small-scale fishermen in the Gulf of California, Mexico, have ownership rights to fishing grounds where they harvest highly valuable commercial species of bivalves. Outsiders are eager to gain access, and the community has devised a set of rules to allow them in. Because Seri government officials keep all the economic benefits generated from granting this access for themselves, community members create alternative entry mechanisms to divert those benefits to themselves. Under Hardin's model of the tragedy of the commons, this situation would eventually lead to the overexploitation of the fishery. The Seri people, however, are able to simultaneously maintain access and use controls for the continuing sustainability of their fishing grounds. Using insights from common-pool resources theory, I discuss how Seri community characteristics help mediate the conflict between collective action dilemmas and access and use controls.
\end{abstract}

Keywords access controls, common-pool resources, community-based management, Gulf of California, Mexico, marine protected areas, self-governance, Seri people, small-scale fisheries, tragedy of the commons

Access controls play a central role in a group's ability to manage its common pool resources (CPRs) (Ostrom, Gardner, and Walker 1994). A CPR is "a valued natural or human-made resource or facility that is available to more than one person and subject to degradation as a result of overuse" (Dietz et al. 2002, 18). In CPRs, (1) exclusion of potential users is very difficult or costly and (2) resource units extracted from the pool are no longer available to the commons (Dietz et al. 2002, 18). Fisheries, forests, irrigation resources, groundwater basins, and natural protected areas are CPRs. In open access CPRs, appropriators find no incentives to invest in the sustainability of the resource. Due to the high level of uncertainty of future resource availability, every user is motivated to maximize

Received 12 March 2004; accepted 20 December 2004.

Financial support was generously provided by the Consejo Nacional de Ciencia y Tecnología (CONACyT), the Inter-American Foundation, and the Wallace Research Foundation. This article benefited from comments from Edella Schlager, Charles Ragin, Tanya Heikkila, Luis Bourillón, Jorge Torre, Rocío Covarrubias, Richard Cudney and three anonymous reviewers. Brooke Gebow's excellent editing skills are much appreciated. Heartfelt thanks to the Seri (Comcáac) community, and especially to the López Morales and Valenzuela families.

Address correspondence to Xavier Basurto, School of Public Administration and Policy, McClelland Hall 405, University of Arizona at Tucson, 1130 E. Helen St., Tucson, AZ 857210108, USA. E-mail: xbasurto@u.arizona.edu 
present benefits before others do the same (Hardin 1968). In the mid 1950s, scholars agreed that limiting access to open-access fishing grounds was an important step to avoiding resource abuse and economic loss (Gordon 1954; Scott 1955). However, privatization and centralized controls are not the only strategies users employ to control access to their resources as some scholars suggested (Hardin 1968). Communities around the world rely on a variety of common property institutions to control access to their resources, and many hybrids between private, governmental, and communal property rights exist (see Pinkerton 1989; Feeny et al. 1990; Katon et al. 1999; Pomeroy and Beck 1999; Berkes 2002). Since the 1980s, hundreds of cases of long-term use of CPRs using common property institutions have been documented (Hess 2003). These cases represent fisheries as well as forest resources, rangelands, irrigation systems, and underground water basins (McCay and Acheson 1987; Berkes 1989; Pinkerton 1989; Feeny et al. 1990; Ostrom 1990; Blomquist 1992; Bromley 1992; Tang 1992; Berkes and Folke 1998). Some important lessons have been learned from these studies. As pointed out most recently by Dietz, Ostrom, and Stern (2003), successful commons governance is easier to achieve when (1) use of resources can be monitored by community members at low cost; (2) changes in resources, user populations, technology, and other economic and social factors take place at moderate rates; (3) community members maintain direct communications and increase their trust of one another; (4) outsiders can be excluded from using the resource at relatively low cost; and (5) users are able to monitor and enforce their collectively designed agreements themselves.

While CPR scholars have paid increasing attention to how community members are able to devise rules to control access and use to avoid overexploitation of their CPRs (Ostrom 1999), much less attention has been given to the question of how access and use controls operate once they are in place. What shape might they take? This article attempts to provide such explanation through the example of a selfgoverned small-scale fishery managed by the Seri Community in the Gulf of California of northwest Mexico.

The Seri are an autonomous native hunter and seafarer group granted with exclusive fishing rights in 1975 by the federal government (Diario Oficial de la Federación 1975). Due to the abundance of fishing resources (in comparison to open access areas nearby), and pressure from outside fishers to gain access to its fishing grounds, the Seri communal government has established rules to give access and withdrawal rights to outsiders, who then become "authorized users" (see Ostrom and Schlager 1996, 133). I refer to this rule configuration as the "formal" entry mechanism. Although legally the Seri cannot transfer fishing rights to outsiders, this is a common practice because the federal government has neither presence nor authority inside Seri waters. The Seri government official who receives the fee assigned for granting access and withdrawal rights to outsiders commonly keeps it for himself or his family, since Seri social structure is based on the family clan. Clan is socially defined in terms of actual descent from a common ancestor. Among the Seri it consists of parents and children but sometimes includes grandparents and grandchildren. Other community members, however, realize that a few individuals capture most of the economic benefits (mostly in the form of fees) of granting access and withdrawal rights to outsiders, but the costs of the loss of their fishing resources are born by all. As a result, members of the community devise their own sets of rule configurations by which outsiders can become authorized users to Seri 
fishing grounds. This strategy allows individuals in the community to capture for themselves the benefits that the presence of outsiders can bring, before others do the same.

From the perspective of an outside fisher the result is the emergence of different paths by which they can gain access to Seri fishing grounds. I refer to the different sets of rule configurations that community members have devised as the "informal" entry mechanisms. The conflict between Seri government officials and community members to appropriate the economic benefits that the presence of outsiders can bring means that access can be achieved either through "formal" or a various "informal" entry mechanisms. This situation resembles the scenario that Hardin (1968) portrayed in his seminal article describing the tragedy of the commons. The tragedy of the commons model predicts that when individual and group interests are in opposition, individual self-interest will always come ahead of the common goal. In this light, successful organization for collective action and management of communal natural resources, such as fisheries, would not be possible, and overexploitation would be unavoidable. Hardin (1968) proposed that the "only way" to avoid this tragedy was by appointing a centralized authority in charge of organizing exploitation, or by privatizing the resource so the owner would be able to find incentives to plan use in a sustainable manner.

Thus, the tragedy of the commons model predicts that Seri government officials and community members' self-interest in becoming the sole beneficiaries of the available-to-all resource (the monies that outsiders pay to get in) will inevitably lead to too many outsiders using the Seri fishing grounds. While Seri individuals will economically benefit from granting access and withdrawal rights to outsiders, the community as a whole will be unable to control access, and thus overexploitation of the fishing resources will take place once pressure from outside fishers surpasses the resource regeneration capability of the fishery. Examples of commons tragedies have been well documented in the literature (see compilation by Hess 2003). Some show that even when fishers had devised rules, their inability to prevent the entry of new fishers led to crowding, rent dissipation, and likely resource overuse (Alexander 1977; Berkes 1986; Cordell and McKean 1992).

This tragedy, however, has not presented itself in the Seri fishery. As this article describes, the Seri have been able to sustain relatively constant rates of fishing effort over time, while other open access and ecologically similar fishing areas (outside Seri control) have not been able to do the same. How are the Seri able to avoid the tragedy of the commons? What are the institutional mechanisms inside the Seri community that have allowed them to control access, fishing effort, and prevent overexploitation despite their internal disputes? To answer these questions, this article first presents the general research methods used to identify the rules-inuse by the Seri people to manage their fishing grounds. Second, I describe the physical and communal setting that allowed for the emergence of communal rules to control access to Seri fisheries. Third, I introduce the rule typology developed by Ostrom, Gardner, and Walker (1994) and apply it to classify the rules-in-use that govern each entry mechanism ("formal" and "informal"). Fourth, I explain how the Seri are able to avoid overfishing given the different rule configurations under which outsiders are able to gain entry. I conclude that the presence of boundary and scope rules across all different entry mechanisms is responsible for the Seri people's ability to maintain access and use controls, which in turn support the continued sustainability of their fishing system. 


\section{Methods}

I began interacting and building trust, reciprocity, and general rapport with the Seri community in 1998, when I temporarily settled in the area. Most of the data were later collected on several field trips between June 2000 and June 2001. I used participant observation techniques, including informal and unstructured interviews with fishers operating in the Seri fishing grounds (both Seri and non-Seri fishermen visiting from other communities). I participated in 32 fishing trips. Each trip lasted 5-8 hours, during which time the number of fishing boats, their origin, the number of crew members per boat, and their ethnicity were recorded. When participation in fishing trips was not possible, this information was obtained from informal interviews at fishers' return from sea or formal interviews of key informants once they had been identified. Identification of the most experienced fishers in the community as reliable informants was accomplished over a long period of time, through conversations with fishers during fishing trips and in their homes and through interaction with community members in general.

Initially, my selection of fishing trips was opportunistic and biased toward those fishermen who already knew me well and were willing to take an extra person in their small boats. It progressively included others as they got used to my presence in the community. They became increasingly curious about me, and my reputation as relatively useful free labor grew. At that point I started receiving invitations to go to sea from Seri and non-Seri fishers I had not met yet, including those coming from nearby villages on a short-term basis. Clearly, the selection of fishers from which this study is based was not random. It included only those fishers who were willing to take me on their boats and share their knowledge and experiences with me. According to my estimates, I was able to go out fishing with or interview about $70-80 \%$ (48-56) of the fishermen operating in the Infiernillo Channel. This process allowed for the identification of all the mechanisms used by Seri and the outside fishermen to control and gain access to the fishing grounds during the period that the study was conducted. Each entry mechanism consisted of a particular combination of rules-in-use that the Seri devised to grant access to outsiders. Rules were defined after Crawford and Ostrom (1995), who described rules as mutually understood prescriptions (must, must not, or may) that are enforced in predictable ways by those responsible for monitoring and sanctioning rule breakers. Once rules-in-use were identified, they were classified under the Ostrom et al. $(1994,41)$ rule typology. This classification organizes rules into seven broad rule types. For instance, according to Ostrom (1999, 509), "(1) Boundary rules affect the characteristics of the participants (2) position rules differentially affect the capabilities and responsibilities of those in positions; (3) authority rules affect the actions that participants in positions may, must or must not do; (4) scope rules affect the outcomes that are allowed, mandated, or forbidden; (5) aggregation rules affect how individual actions are transformed into final outcomes; (6) information rules affect the kind of information present or absent in a situation; and (7) payoff rules affect assigned costs and benefits to actions and outcomes" (see Ostrom et al. 1994 for examples of each rule type). This analysis identified the key rule types applied when Seri government ("formal" mechanism) or community members ("informal" mechanisms) regulate use and grant access to outsiders. 


\section{The Setting: Fishery, People, and Institutions}

Callos de hacha (CDH) are bivalve mollusks also known as sea pen shells or fan clams. In Spanish their colloquial names vary: callos, callo riñón, callo redondo, callo media luna, callo rosado. The species of CDH harvested by the Seri are Atrina tuberculosa, A. maura, and Pinna rugosa. This benthic sessile mollusk is exploited for its abductor muscle. It is considered a delicacy and brings high prices in national and international markets. In 2001 the price of a kilogram of $\mathrm{CDH}$ paid to fishers ranged between $\$ 9$ and 18 USD. The Seri CDH fishery is confined to the Canal del Infiernillo (Infiernillo Channel), a long $(41 \mathrm{~km})$, narrow, and shallow (average depth $5.5 \mathrm{~m}$ ) body of water that runs north-south in the central portion of the Gulf of California (Torre-Cosío 2002). The channel is flanked on the west by Tiburon Island and to the east by the continental coast of the state of Sonora. The narrow southern mouth of the channel is $1.8 \mathrm{~km}$ wide, while its northernmost portion is $10 \mathrm{~km}$ wide (Figure 1).

The Seri CDH fishery is one of many Mexican small-scale fisheries not actively regulated by the federal government. Therefore, it is widely perceived that the fishery is entirely managed by the Seri community of Punta Chueca (see Figure 1), one of the two Seri permanent settlements (the other being El Desemboque). The Seri total population is about 425 people (INEGI 2000).

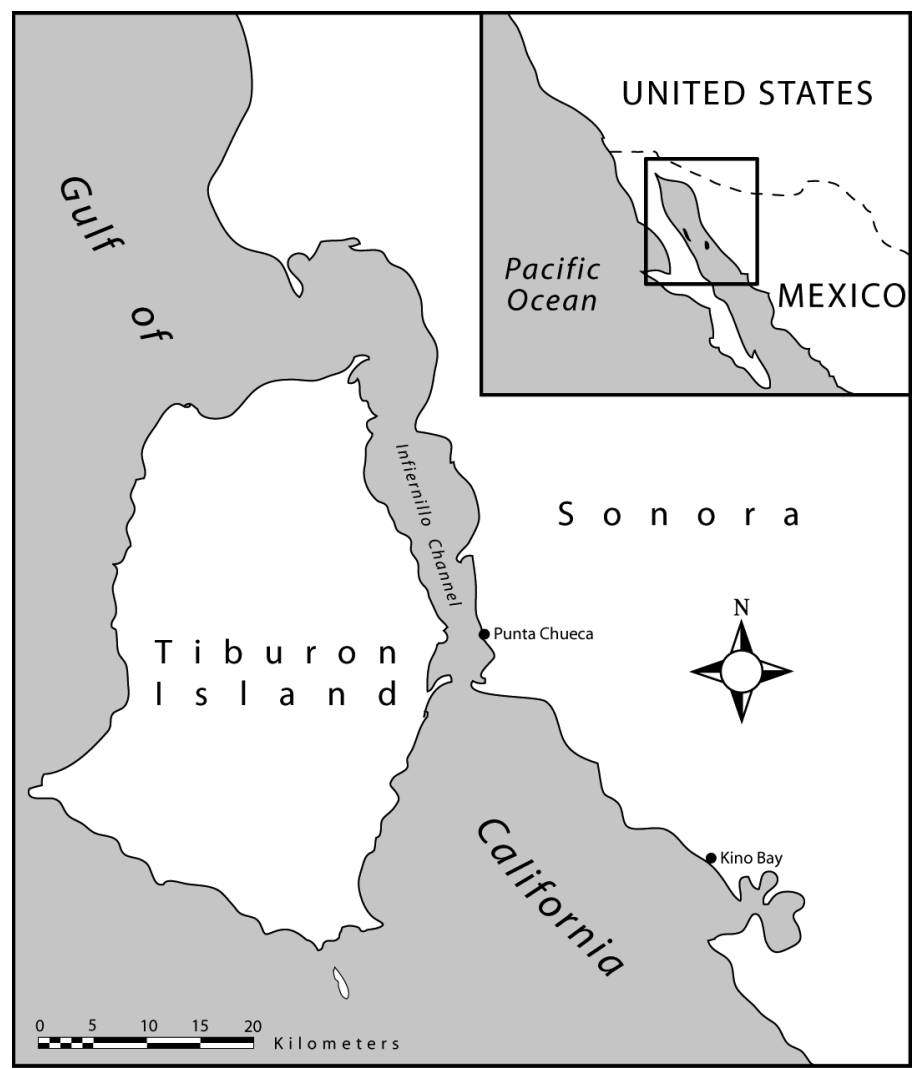

Figure 1. The infiernillo channel. 
The Seri Indians have inhabited the coast of one of the driest portions of the Sonoran Desert for hundreds of years. In a region where neither agriculture nor farming is feasible, fishing became the main source of income as soon as a cash economy appeared. As low-income farmers from the south were lured to the coast by the once abundant source of fish in this region, other coastal towns started to emerge by the early 1900s. In the 1970s the federal government legally granted the Seri Indians property rights to a portion of their historic coastal territory, in the form of ejido de El Desemboque and its annex of Punta Chueca (Diario Oficial de la Federación 1970), Tiburón Island (Diario Oficial de la Federación 1978), and a fishing concession, as a way to guarantee the survival of this small tribal culture and reduce conflicts with other rapidly growing local fishing communities (Diario Oficial de la Federación 1975). The configuration of the Infiernillo Channel (see Figure 1) makes it the only section of the fishing concession where the Seri are able to monitor entrance and exit of non-Seri fishermen (Bourillón 2002). The combination of legal and physical factors allowed the Seri to define the spatial extent of their exclusive fishing grounds: the Infiernillo Channel. This contrasts with the de facto open-access regime that prevails in the rest of the fishing concession.

Small-scale fisheries catch data have not been systematically collected in Mexico; thus, stock assessment figures are not available. Historical accounts show that since the first beds of callo riñon were discovered in 1978 in the Infiernillo Channel the catch has remained relatively stable. The fish buyer at the time, Mr. Orta, used to receive between 400 and $600 \mathrm{~kg}$ daily from all fishers, 20 to 25 in total. In 2000 and 2001, buyer Sergio Padrés was receiving the 100-500 kg catch of a similar number of fishermen that amounted to 70 to $80 \%$ of the Infiernillo Channel's daily catch. It is vox populi among local and regional fishermen that the Infiernillo Channel is rich in $\mathrm{CDH}$ beds compared to the open-access fishing grounds nearby (Chenaut 1985, 88). For instance, the open-access waters surrounding the town of Kino Bay, where fishing is also the main source of income (see Figure 1), cannot sustain the fishery year-round, unlike in the Infiernillo Channel. Even during the months that the Kino Bay fishery takes place, its best fishing areas (as indicated by frequency of use) are those lying just outside the Infiernillo Channel. Even in these fishing areas the catch is still lower and the number of fishers larger than those registered inside the Infiernillo Channel (Moreno and Durazo 2004).

Inside the Infiernillo Channel the Seri people harvest CDHs in two ways. The profit-driven "commercial fishery" relies on boats and underwater breathing equipment called hookahs. In the Gulf of California, commercial small-scale CDH fishing generally employs a rudimentary hookah underwater breathing system adapted to a small $(\sim 8 \mathrm{~m})$ fiberglass outboard motor boat known as a panga. The number of crew members varies between two and four. The usual lineup consists of one (but sometimes two) buzos (divers), a popero (stern man), and a matador (CDH meat preparer).

In contrast, the "subsistence/semicommercial fishery" is motivated by a culturally important subsistence practice, hundreds of years old, based on manual harvesting of sandbars at low tide intervals. These sandbars, where shallow water makes underwater breathing apparatus unnecessary, are reserved for the exclusive use of this fishery. It is understood among Seri community members that all other $\mathrm{CDH}$ beds in the Infiernillo Channel are open to the use of commercial divers.

Mainly the nonfishing members of the Seri community take part in the traditional harvest. Year after year during the lowest tides of the summer, Seri children, 
adults, and the elderly travel to their old fishing camps along the Infiernillo Channel, camping and harvesting $\mathrm{CDH}$ together. This event is known as the callo de bajamar (intertidial pen shell), callo parado (standing pen shell), or el callo de mujeres y niños (pen shell for women and children). Male adults who participate are mainly those who lack fishing gear needed to join the commercial fishery. In times of economic hardship, this event brings food and monetary resources to the community. However, it also provides an appropriate setting for the exchange of experiences and information among the elderly, women, children, and nonelderly male adults, helping the Seri to perpetuate communal ecological knowledge about traditional CDH harvesting sites. Moreover, it also reinforces family bonds, and a collective connection to the sea. Seri believe that this annual event remains as a silent testimony to a past nomadic subsistence practice, when their people seasonally camped alongside the Infiernillo Channel and harvested bivalves in times of scarcity (Felger and Moser 1985). Today, this practice plays an important role in the community's ability to monitor the activities of the hookah commercial diving fleet and is thought to contribute to the Seri ability to avoid overexploitation of their fishery, as is further discussed later.

Cooperation among the Seri seems to be mostly restricted to immediate kin: parents and siblings. Thus, cooperation between members of different families or with outsiders requires a material incentive, usually money. Interfamily conflicts are considered a serious matter and can continue long after a dispute has been resolved. As a consequence, the authority that members of the Seri government can exert over internal rule breakers is limited. Official actions against community members are taken personally, and retaliation against the Seri government official or his family can be expected. Thus, Seri authorities usually try to avoid getting involved in disputes. On the other hand, when faced with external threats, the Seri act as a cohesive group. This trait played an important role in Seri survival of the extermination wars that the Spanish and Mexicans waged against them in the 18th, 19th, and early 20th centuries (Sheridan 1999). These events earned Mexicans the Seri's longstanding animosity and distrust.

The involvement of Mexican local or federal government in Seri internal issues is limited to certification of Seri government elections. From an outsider's perspective the Seri territory is a place that does not operate within the confines of the Mexican government authority. However, when the Mexican government granted the Seri terrestrial and marine ownership rights in the 1970s, it also imposed upon them the ejido system and the fishing concession as their institutional structure. In Mexico an ejido is an area of farmland held in communal ownership but divided into separate family plots. Until recently, members of the ejido had no right to sell their land (Taylor 2003).

The most important and powerful political structure in the community is the traditional government, headed by the governor and his appointed cabinet members. Because the Seri do not collect taxes, the traditional government functions on the monies received from government subsidies or fishing access fees and sale of hunting permits inside their territory. Since there is no system in place to account for the money that enters the government's coffers, the traditional governor and his cabinet have absolute discretion in spending it. The enforcement body of the traditional government is the Guardia Tradicional (Seri Traditional Army), an informal and undisciplined group of men made up of squads of 8 to 10 young Seri commanded by a squad chief. Its main task is to police poachers on Seri territory. 


\section{"Formal" and "Informal" Entry Mechanisms to Seri Fishing Grounds}

Although the Seri fishing concession stipulates that only members of the Seri community or fishing cooperative are allowed to fish in its waters, the Seri find it acceptable to grant access to outsiders when they agree to comply with the Seri government rules. Seri entry requirements are widely recognized among non-Seri fishermen as the "formal" path to fishing in Seri waters.

\section{Entry Mechanism 1 (Formal): Obtaining Access and Withdrawal Rights from the Seri Government}

Entry requests are made to members of the Seri traditional government. As articulated by them, if access and withdrawal rights are to be granted, outsiders must agree to comply with all of the following rules: (1) Pay an access fee, determined as the value of $1 \mathrm{~kg}$ of $\mathrm{CDH}$ per day; (2) direct the payment to Seri Government officials; (3) hire a Seri as part of the fishing crew; (4) pay the Seri crew member the same share as the rest of the fishing team; (5) avoid fishing in the community's culturally important ("subsistence/semicommercial") sandbar areas; and (6) comply with the current maximum allowable catch, determined as a maximum of $20 \mathrm{~kg}$ per day in 2000 and 2001.

Following Ostrom et al. (1994), boundary rules (1, 2, and 3 above) specify how non-Seri fishermen can gain access to the Seri Infiernillo Channel. Payoff rules determine how benefits and costs (in this case monetary payments, rule 4 above) are distributed between Seri and non-Seri crew members. Scope rules specify outcomes that may be affected by non-Seri fishers' actions. In this case rules 5 and 6 described earlier specify off-limits fishing locations and the maximum $\mathrm{CDH}$ harvest from the authorized fishing areas. Authority rules cover the actions possibly taken by Seri on behalf of non-Seri fishers within the Seri fishing grounds. Under this "formal" entry mechanism, the authority rules protect non-Seri fishers from communal harassment.

Rules for entry mechanism 1, described in Table 1 (boundary 1, 2, 3, scope 1 and 2, authority, and payoff), constrain outside fishers' incentives by decreasing the profit margin of the fishing venture while increasing the transaction costs of seeking access. Boundary and payoff rules compensate the community for granting access and withdrawal rights to outsiders. Scope rules help the Seri to protect important ecological and cultural marine sites as well as control fishing effort. The mandate that a Seri fisherman be hired on fishing crews (boundary rule 3) can allow monitoring outsiders' activities at a low upfront cost for the community. Monitoring of outsiders' activities such as fishing in culturally sensitive areas, which are off-limits to the diving fishermen, will vary individually, according to the context and the fisher's own cost-benefit calculations.

It is important to point out that because profit margins are tight, those outside fishers who agree to hire a Seri as part of the crew usually leave one of their own at home. Outside fishers are not economically powerful, and many of them agree to come to the channel only because they do not catch enough in their own open access fishing grounds. Their situation is typical of most small-scale fishers in the region, where fishers pay their expenses on a day-to-day basis and are strapped for cash all the time.

I observed that non-Seri fishers followed "formal" procedure on only 11 occasions (entry mechanism 1 in Table 1), while they used "informal" access strategies 76 times (entry mechanisms 2, 3, 4, and 5 in Table 1). Brief descriptions follow of 


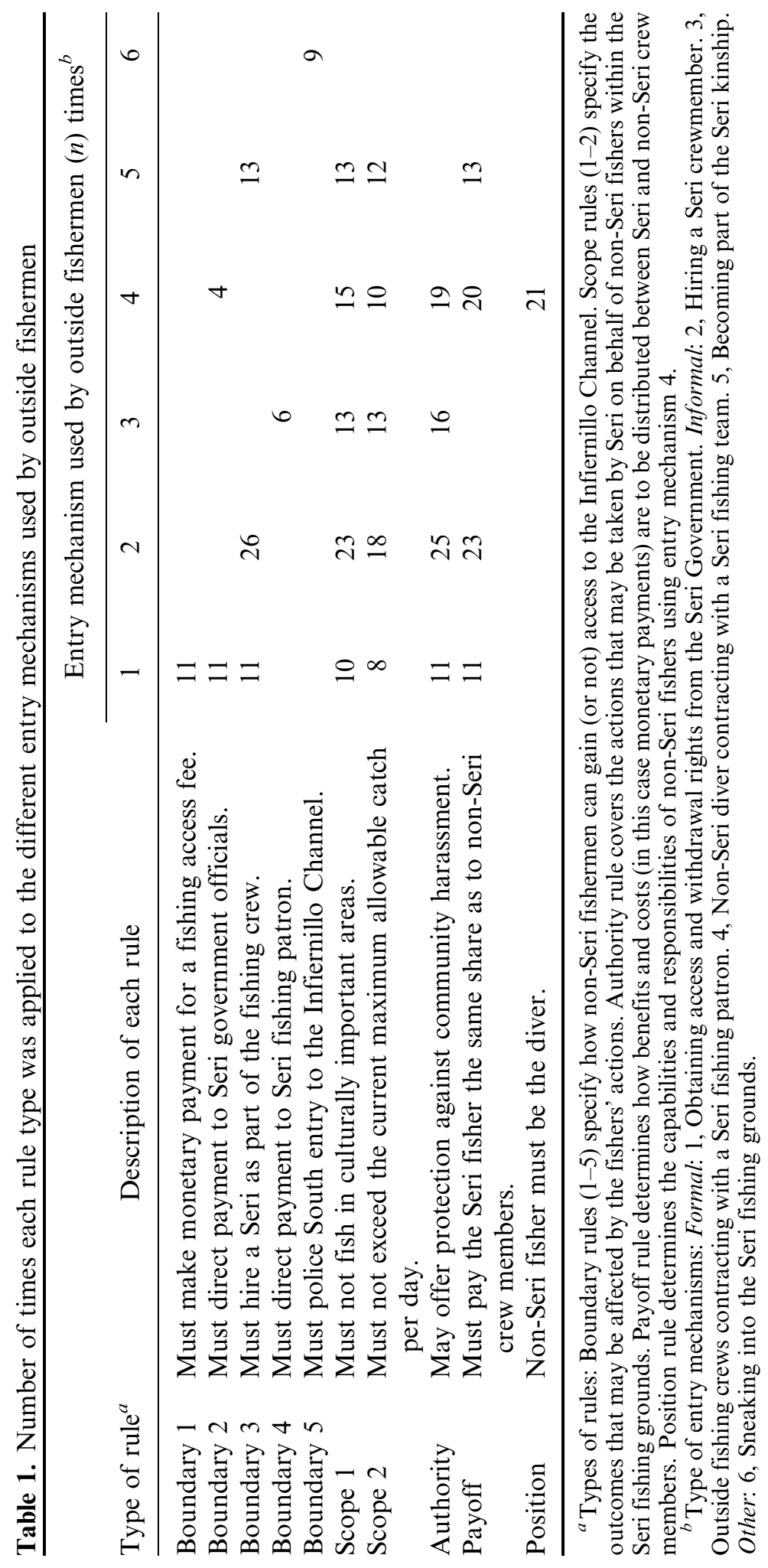


"informal" mechanisms used by outside fishers diving in the Infiernillo Channel observed during 2001 and 2002.

\section{Entry Mechanism 2 (Informal): Hiring a Seri Crew Member}

This most common $(n=26)$ strategy is similar to the "formal" one, except that non-Seri fishers bypass boundary rules 1 and 2 to avoid paying the access fee (see Table 1).

Under mechanism 2, Seri fishermen recruit outside fishing teams to come to the Infiernillo Channel in exchange for employment. Recruiters usually do not hold official positions in the local government and thus do not benefit from access fee revenues. They generally do not own boats or diving gear; thus, this mechanism gains them access to their own fishery.

During hard times, Seri are likely to offer themselves as the outsiders' "passport" to fish in Seri waters. Lack of coordination among the Seri Army and government officials makes it difficult to determine who has paid and who has not. Although for outside fishers the access fee savings might be offset by the cost of sharing the profit with one extra crew member, the presence of a Seri guide effectively reduces the risk of economic failure of fishing in unknown waters. The Seri crew member can also alert outsiders to upcoming army raids, so they can leave the channel before having their harvest and fishing gear confiscated. On the other hand, he can also act as a fishing observer, making sure that scope rules 1 and 2 are enforced.

\section{Entry Mechanism 3 (Informal): Outside Fishing Crews Contracting With a Seri Fishing Patron}

In Mexican small-scale fisheries, a permisionario (fishing patron) is an individual who makes a living marketing fish. In order to guarantee a constant supply of product, patrons provide boat, motor, diving compressor, and gasoline to a pool of fishers who work for them. Sometimes members of the Seri community become fishing patrons for non-Seri fishing teams, but they are not necessarily as economically powerful as their counterparts elsewhere. A Seri fishing patron might grant access to outside fishers by renting them his equipment in exchange for a portion of the catch. Patrons also receive payment for providing supplies such as food and gasoline, marketing the catch, and protecting outsiders from possible army raids. Because unauthorized fishing teams must remain undetected by the Seri traditional government, they usually camp in remote locations alongside the Infiernillo Channel. Thus the fishing patron is their lifeline inside the Seri territory. The significant bargaining power that the Seri patron enjoys originates from outsiders' complete dependence on his continued support to fish in the Seri fishing grounds. Fishing patrons do not always go to sea, so they can oversee more than one outside team and multiply their income.

Entry mechanism 3 was observed 16 times. Table 1 describes the rule configuration that defines it. Notice that payment to Seri fishing patrons is a boundary rule (boundary rule 4 in Table 1) not applying to any other entry mechanism. The high degree of compliance observed for scope rules (Table 1) might be due to outsiders' realization that improper behavior is likely to attract unnecessary attention (from the rest of the fishing fleet). 


\section{Entry Mechanism 4 (Informal): Non-seri Diver Contracting With a Seri Fishing Team}

Individual outside fishers joining Seri fishing teams was the second most observed "informal" entry mechanism $(n=21)$. Many Seri preferred to hire outside divers for this hazardous and exhausting undertaking that they would rather avoid, especially if the catch is to be distributed equally among all crew members. Also, many Seri cannot afford a wetsuit, mask, fins, and harvesting hook, which cost in 2001 about US\$500. Moreover, many non-Seri divers have more hookah diving experience and are used to rough conditions. Thus, the rule configuration for this entry mechanism is characterized by the presence of a position rule that requires non-Seri fishers to be divers (Table 1). Non-Seri divers are attracted year-round to the unusual resource abundance and shallow (average $5.5 \mathrm{~m}$ ) waters of the Seri fishing grounds. Depths elsewhere in the region exceed $10 \mathrm{~m}$, which significantly increase the risk of diving-related diseases (Fernandez 2003). Most standards allow diving for extended periods of time only at depths of less than $10 \mathrm{~m}$ ( $2 \mathrm{~atm}$ of pressure) (Martin 1997). Seri fishing captains provide outside divers a place to sleep and protection against community harassment as long as they have a working relationship. Regionally, there is a sense of pride in being a diver, and divers generally lead fishing expeditions (also see Cudney-Bueno 2000). However, this traditional role disappears when divers are hired by Seri fishing patrons. Their sole duty is to harvest CDH underwater, and they have no other say or authority relative to any other aspect of the fishing operation. Most divers tolerate this humiliating situation because diving is safe and profitable in Seri waters.

\section{Entry Mechanism 5 (Informal): Becoming Part of the Seri Kinship}

Mexicans married to a Seri obtain immediate rights to all Seri CPRs. Most males become fishers after establishing residence in the Seri village. This entry mechanism was observed 13 times between 2000 and 2001 (Table 1). Mexicans married to Seri women account for one of every three active fishers in the community (Bourillón 2002). Once a non-Seri person is established in the Seri community, his or her extended family living elsewhere can also gain access to the fishery. Some non-Seri extended family members have made fishing in the Seri Infiernillo Channel a seasonal job. They arrive at the village and live with their relatives at times when there is no work elsewhere. When Seri social pressure mounts, they leave.

Non-Seri living in the Seri community take specific actions to avoid unwanted attention from Seri fishers. For instance, in several interviews non-Seri expressed that they always avoid being the first boat to go out or the last one to return. They never brag about exceptional catches in the presence of fellow Seri fishermen, as fishermen customarily do. Their success could generate feelings of envy and potentially result in their expulsion from the village. Likely for these reasons, I observed a high level of compliance with the rules that constitute this entry mechanism (Table 1).

\section{Entry Mechanism 6: Sneaking Into the Seri Fishing Grounds}

Sneaking into the Seri Infiernillo Channel is not considered to be an "informal" entry mechanism because Seri participation is minimal and because available data were unreliable. However, it is important to acknowledge this access and how the Seri manage it. Because the secretive entrance of non-Seri fishers to the channel is 
difficult to document, generalized talk among Seri fishers about the presence of outside fishers was used as a proxy to estimate occurrence. It is likely that the nine observations reported in Table 1 underestimate actual occurrence. Entering and leaving the Seri fishing grounds on a daily basis is uncommon (although gaining popularity), since it considerably increases gas costs and reduces profit margin. Fishers prefer to camp alongside the Infiernillo Channel for a few days. The narrow southern mouth of the channel is close enough to the village of Punta Chueca that any boat entering or leaving the channel can be seen or its outboard motor heard. Entering the channel from the north is not popular among fishers coming from Kino Bay, the non-Seri fishing village closest to the channel (see Figure 1), due to a 2-hour detour around Tiburón Island, Mexico's biggest. When the influx of outside "pirates" rises to unusual levels, the Seri Army patrols the channel entrance. This boundary rule (boundary rule in Table 1) is the only one the Seri use to discourage non-Seri fishers from sneaking in (Table 1). Apprehended catch is generally seized and sold by members of the Seri government for their own profit. Overall, the appeal of sneaking into the Infiernillo Channel seems to be influenced by the lack of fishing elsewhere, market price of $\mathrm{CDH}$, Seri internal tolerance toward outsiders, and the non-Seri fishers' own risk perception.

\section{Can the Seri Control Access to Their Fishing Grounds?}

After all rules-in-use for each entry mechanism were classified according to the Ostrom et al. (1994) rule typology, they were aggregated by type to determine which were common across all entry mechanisms (Table 2).

Boundary rules were present in all entry mechanisms. Because boundary rules identify the conditions that must be met by outsiders to gain access, their presence for each entry mechanism indicates that despite internal conflicts, the Seri community has devised access controls to manage all entry mechanisms. Contrary to

Table 2. Summary of rule types observed for each entry mechanism

\begin{tabular}{|c|c|c|c|c|c|c|}
\hline \multirow[b]{2}{*}{ Rule types $^{a}$} & \multicolumn{6}{|c|}{ Entry $_{\text {mechanisms }}^{b}($ dark cell $=$ rule type observed $)$} \\
\hline & 1 & 2 & 3 & 4 & 5 & 6 \\
\hline \multicolumn{7}{|l|}{ Boundary } \\
\hline \multicolumn{7}{|l|}{ Scope } \\
\hline \multicolumn{7}{|l|}{ Authority } \\
\hline \multicolumn{7}{|l|}{ Payoff } \\
\hline Position & & & & & & \\
\hline
\end{tabular}

${ }^{a}$ Types of rules: Boundary rules specify how non-Seri fishermen can gain (or not) access to the Infiernillo Channel. Scope rules specify the outcomes that may be affected by fishers' actions. Authority rules cover the actions that may be taken by Seri on behalf of non-Seri fishers within the Seri fishing grounds. Payoff rules determine how benefits and costs (in this case monetary payments) are to be distributed between Seri and non-Seri crew members. Position rules determine the capabilities and responsibilities of non-Seri fishers.

${ }^{b}$ Type of entry mechanisms: Formal: 1, Obtaining access and withdrawal rights from the Seri Government. Informal: 2, Hiring a Seri crew member. 3, Outside fishing crews contracting with a Seri fishing patron. 4, Non-Seri diver contracting with a Seri fishing team. 5, Becoming part of the Seri kinship. Other: 6, Sneaking into the Seri fishing grounds. 
what the tragedy of the commons would predict, the "race" between Seri government officials and community members for money from outside fishers does not produce a free-for-all. Seri fishers do not grant unconditional access to outsiders in purely self-interested fashion. As shown in the preceding section, "informal" entry mechanisms designed to bypass "formal" ones also stipulate controls on outsiders' access.

\section{How Have the Seri Been Able to Avoid Overfishing?}

Controlling access to a resource does not automatically prevent overexploitation. Fishers with access and withdrawal rights to the Infiernillo Channel could drive the resource to extinction unless there are scope rules that limit fishing effort.

As indicated in Table 2, scope rules were present in all "formal" and "informal" entry mechanisms ( 1 to 5 ) used by outsiders to gain access to the Infiernillo Channel. Scope rules identify the set of outcomes from a particular set of actions. In this case, scope rules specify harvesting places and maximum allowable catch to the commercial fishing fleet. Fishing places designated for "subsistence/semicommercial" activities are off-limits for the commercial fishing fleet. Recall that the noncommercial fishing members of the community mainly conduct traditionally important "subsistence/semicommercial" harvesting a few times a year. Thus, it is likely that a Seri crew member on board (mandated by a boundary rule) facilitates the enforcement of scope rules most of the time. This enforcement is highly relevant to the sustainability of the fishery over time, since it is likely that less disturbed CDH banks contribute to the repopulation of all other $\mathrm{CDH}$ banks used by the commercial fleet throughout the year. It was unusual to observe Seri crew members directing outsiders to fish in forbidden areas, and it happened only as a last resort, such as when catch suffered at permitted fishing spots. In these situations the incentives for Seri fishers are related to the presence of payoff rules that identify how benefits and costs are assigned among a set of actors. Here payoff rules determine that Seri fishers must be paid the same share as non-Seri crew members (Table 1). The better the fishing team does as a whole, the better the individuals fare, and Seri crewmembers are tempted to direct boats to the most profitable fishing places. Advice often also includes warning of upcoming Seri army patrols. An encounter with a patrol by a fishing team lacking "formal" access would likely result in loss of the day's catch, and in extreme circumstances it would include the seizing of the fishing equipment. Needless to say, both situations would be detrimental to the Seri crew member's economic interests. Without scope rules, Seri crew members would likely find few incentives to regulate outsiders' fishing effort, and overfishing would eventually take place as fishing pressure increased.

\section{How are Rules Designed to Prevent Overfishing Enforced?}

It is difficult to tell whether fishers entering the Infiernillo Channel are visiting offlimits fishing places or respecting the maximum allowable catch (scope rules 1 and 2, respectively; see Table 1). One would need to observe every boat all the time which is not possible. However, the Seri can detect fishing in prohibited sites through the "subsistence/semicommercial" harvesting practices. These practices enable the nonfishing community members to make annual assessments of the state of their fishing resources and to monitor the activities of the commercial hookah fishing fleet. The 
monitoring of fishing effort and use patterns of the commercial hookah fishing fleet is an important enforcement mechanism at the level of the Seri community. Recall that these "subsistence/semicommercial" sites are sandbars where the Seri children, adults, and the elderly have harvested CDHs and other bivalve mollusks for hundreds of years during the lowest "spring" tides of summer. To successfully harvest the buried bivalves it is necessary to know the tides and their interaction with sandbars. In the Infiernillo Channel the tidal currents uncover the sandbars to varying degrees throughout the year, depending on the amplitude of the tides. Depending on their location, shape, height, and tidal amplitude, sandbars can be exposed from a few minutes to several hours per occasion. Therefore, the knowledge of when, where, and which sandbars are going to be exposed has to be very precise if buried mollusks are to be successfully harvested before the water has covered them again. This detailed knowledge helps community members notice differences in abundance from one harvesting event to the next. When members discover smaller size or lower abundance of $\mathrm{CDH}$ than expected at a given location, they usually think that commercial divers have been harvesting there against communal agreements (a clear violation of scope rule 1) and may take action against the diving fleet. Several times such actions took the form of groups of women humiliating their husbands in public by yelling and showing signs of disrespect to them that are usually reserved for private contexts. Concerned commercial Seri fishers, in turn, blame outsiders, and, given enough communal pressure, outsiders are expelled from Seri waters. Depending on the "communal mood," outsiders can be given 1 or 2 days' notice to leave, or be rushed out by the Seri Traditional Army. When communal tolerance toward the presence of outsiders improves and the Seri are again in economic need, the presence of outsiders increases again.

In sum, it seems that the communal gatherings motivated by the practices of the subsistence/semicommercial fishery provide adequate monitoring of the exploitation patterns of the commercial diving fishery. But note that it is also possible that lower than expected abundance at "subsistence/semicommercial" fishing sites can be caused by various environmental and ecological conditions and not just by the rule breaking of commercial fishers. Either way, outside fishers are ultimately blamed and fishing pressure decreases as they exit Seri fishing grounds.

At the individual level there are other mechanisms by which the Seri are able to overcome self-interested behavior and act collectively to expel outside fishers. For the Seri who engage in granting access to outsiders through "informal" entry procedures, social repercussions vary extensively. The fewer are the economic alternatives available for Seri fishermen, the more tolerant the community is to fishers who find employment by joining an outside fishing crew. However, tolerance decreases toward individuals who routinely prefer to fish with outsiders rather than their own people. Seri who find it worthwhile usually go to great lengths to avoid being seen by other members of the community. For most interviewed Seri, the two most unacceptable practices are the employment as Seri fishing patrons of outsiders and marriage between non-Seri fishers and Seri women. Fishing patrons for non-Seri fishing teams are considered traitors to their Seri blood and village. Many Seri disapprove of interethnic marriages because they believe that the presence of outsiders in Seri territory is a new form of invasion and loss of sovereignty. Seri elders worry that the continuation of interethnic marriages will leave no full-blood Seri, and resources in their territory will be lost to the mestizos (the progeny of Seri and non-Seri parents). For those individuals (in the Seri government or the community) who are in the position 
to grant access to outsiders, these factors influence the calculation of costs and benefits that their self-interested actions will bring to them.

\section{Conclusions}

Contrary to Hardin's (1968) prediction, the case of the Seri CDH fishery illustrates how communities that face tragedy of the commons dilemmas might still be able to develop access and use controls for their fishing resources and avoid overexploitation. Using the Ostrom et al. (1994) rule typology, it was possible to determine that the presence of boundary rules under all entry mechanisms explains the Seri's continued ability to control entry, regardless of who (government officials or community members) grants access and withdrawal rights to outsiders in the first place. Similarly, I found that scope rules play an important role in controlling fishing effort. Together, access and use controls support the continued communal governance of Seri fishing grounds.

These results support the claims made by Dietz et al. (2003) regarding the importance of the presence of institutional mechanisms to exclude outsiders at a low cost as well as the feasibility to monitor and enforce collectively designed rules. Boundary and scope rules for each entry mechanism, as well as high levels of enforcement of most rules-in-use, exist, in part, because the Seri community as a whole values its fishing grounds and interactions with outsiders across a variety of dimensions and not only from a fishing perspective. Thus, the Seri are willing to grant access in exchange for economic gain up to the point where other value dimensions are not compromised. Self-interest has a contingent behavior. When communities own the resource, granting access to outsiders might be motivated not by the presence of a high communal discount rate to it, but by the need of meeting immediate monetary needs. In the Seri case, the availability of low-cost monitoring (assessments by the noncommercial fishing members of the community) and the ability to closely link this with the rules in use for allowing outsiders' access make it possible for the Seri to know when their long-term interests are being threatened and to apply timely corrective measures.

Finally, from a policy analysis perspective, focusing on the function of rules in use allows for a less confounding explanation of the observed outcome. As has been articulated by Elinor Ostrom and colleagues, concrete proposals can then be made to replace rules that have unintended effects or to incorporate others whose function is more desirable for the issue at hand. However, it is important to keep in mind that typologies will be useful analytical tools as long as we do not forget they are human constructs designed to facilitate analysis of processes that in reality most likely exist along a continuum.

\section{References}

Alexander, P. 1977. South Sri Lanka sea tenure. Ethnology 16:231-255.

Berkes, F. 1986. Local-level management and the commons problem: A comparative study of Turkish coastal fisheries. Mar. Pollut. 10:215-229.

Berkes, F., ed. 1989. Common property resources. Ecology and community-based sustainable development. London: Belhaven Press.

Berkes, F. 2002. Cross-scale institutional linkages: Perspectives from the bottom up. In The drama of the commons, eds. E. Ostrom, T. Dietz, N. Dolšak, P. C. Stern, S. Stonich, and E. Weber, 293-321. Washington, DC: National Academy Press. 
Berkes, F. and C. Folke, eds. 1998. Linking social and ecological systems. Management practices and social mechanisms for building resilience. Cambridge, UK: Cambridge University Press.

Blomquist, W. 1992. Dividing the waters. Governing groundwater in southern California. San Francisco, CA: ICS Press.

Bourillón, L. 2002. Exclusive fishing zone as a strategy for managing fishery resources by the Seri Indians, Gulf of California, Mexico. Unpublished PhD dissertation, School of Renewable Natural Resources, University of Arizona, Tucson.

Bromley, D. W., ed. 1992. Making the commons work: Theory, practice, and policy. San Francisco, CA: Institute for Contemporary Studies Press.

Chenaut, V. 1985. Los Pescadores de Baja California (Costa del Pacifico y Mar de Cortés). Serie Los Pescadores de México. Vol. II. México, DF: Centro de Investigaciones y Estudios Superiores en Antropología Social.

Cordell, J. C. and M. A. McKean. 1992. Sea tenure in Bahia, Brazil. In Making the commons work: Theory, practice, and policy, ed. D. W. Bromley, 183-205. San Francisco, CA: Institute for Contemporary Studies Press.

Crawford, S. and E. Ostrom. 1995. A grammar of institutions. Am. Polit. Sci. Rev. 89(3): 582-600.

Cudney-Bueno, R. 2000. Management and conservation of benthic resources harvested by small-scale hookah divers in the northern Gulf of California, Mexico: The black Murex snail fishery. Unpublished MS thesis, School of Renewable Natural Resources, University of Arizona, Tucson.

Diario Oficial de la Federación. 1970. 28 de Noviembre de 1970. México, DF, México.

Diario Oficial de la Federación. 1975. 11 de Febrero de 1975. México, DF, México.

Diario Oficial de la Federación. 1978. 2 de Agosto de 1978. México, DF, México.

Dietz, T., E. Ostrom, and P. C. Stern. 2003. The struggle to govern the commons. Science 12:1907-1912.

Dietz, T., N. Dolšak, E. Ostrom, and P. C. Stern. 2002. The drama of the commons. In The drama of the commons, eds. E. Ostrom, T. Dietz, N. Dolšak, P. C. Stern, S. Stonich, and E. Weber, 3-35. Washington, DC: National Academy Press.

Feeny, D., F. Berkes, B. J. McCay, and J. M. Acheson. 1990. The tragedy of the commons: Twenty-two years later. Hum. Ecol. 18:1-17.

Felger, R. S. and M. B. Moser. 1985. People of the desert and sea. Ethnobotany of the Seri Indians. University of Arizona, Tucson.

Fernandez, E. 2003. Bends in the bay: The nature of risk among commercial diving fishermen in Bahia de Kino, Sonora, Mexico. Unpublished MA thesis, Department of Anthropology, University of Arizona, Tucson.

Gordon, H. S. 1954. The economic theory of a common property resource: The fishery. J. Polit. Econ. 62:124-142.

Hardin, G. 1968. The tragedy of the commons. Science 162:1243-1248.

Hess, C. 2003. The comprehensive bibliography on the commons. Workshop in political theory and policy analysis at Indiana University, 15 July 2003. http://www.indiana. edu/ iascp/Iforms/searchcpr.html, accessed February 2004.

INEGI. 2000. XII Censo general de población y vivienda, 2000. February 2004. http://www. inegi.gob.mx, accessed February 2004.

Katon, B. M., R. S. Pomeroy, L. R. Garces, and A. M. Salamanca. 1999. Fisheries management of San Salvador island Philippines: A shared responsibility. Society Nat. Resources 12(8):777-795.

Martin, L. 1997. Scuba diving explained. Questions and answers on physiology and medical aspects of scuba diving. Flagstaff, AZ: Best Publishing.

McCay, B. J. and J. A. Acheson, eds. 1987. The question of commons: The culture and ecology of communal resources. Tucson: University of Arizona Press. 
Moreno, C. and M. Durazo. 2004. Pescadores Comerciales Promoviendo la Pesca Sustentable en Bahía de Kino, Golfo de California, México. Paper presented at the First International Conference: Coastal Fisheries in Latin America and the Caribbean, "Assessing, Managing and Balancing Actions," Coastfish 2004. Mérida, Yucatán, México, October.

Ostrom, E. 1990. Governing the commons: The evolution of institutions for collective action. Cambridge, UK: Cambridge University Press.

Ostrom, E. 1999. Coping with tragedies of the commons. Annu. Rev. Polit. Sci. 2:493-535.

Ostrom, E., R. Gardner, and J. Walker. 1994. Rules, games, and common-pool resources. Ann Arbor: University of Michigan Press.

Ostrom, E. and E. Schlager. 1996. The formation of property rights. In Rights to nature. Ecological, economic, cultural, and political principles of institutions for the environment, eds. S. S. Hanna, C. Folke, and K. G. Mäler, 127-156. Covelo, CA: Island Press.

Pinkerton, E., ed. 1989. Co-operative management of local fisheries: New directions for improved management and community development. Vancouver, BC: University of British Columbia Press.

Pomeroy, C. and J. Beck. 1999. An experiment in fishery comanagement: Evidence from Big Creel. Society Nat. Resources 12(8):719-739.

Scott, A. D. 1955. The fishery: The objectives of sole ownership. J. Polit. Econ. 63:116-124.

Sheridan, T. E. 1999. Empire of sand. The Seri Indians and the struggle for Spanish Sonora, 1645-1803. Tucson: University of Arizona Press.

Tang, S. Y. 1992. Institutions and collective action: Self-governance in irrigation. San Francisco, CA: Institute for Contemporary Studies Press.

Taylor, P. L. 2003. Reorganization or division? New strategies of community forestry in Durango, Mexico. Society Nat. Resources 16(7):643-661.

Torre-Cosío, J. 2002. Inventory, monitoring and impact assessment of marine biodiversity in the Seri Indian territory, Gulf of California, Mexico. Unpublished PhD dissertation, School of Renewable Natural Resources, University of Arizona, Tucson. 